\title{
FORTIFIKASI IKAN BARAKUDA (Sphyraena jello) DALAM PEMBUATAN TORTILLA CHIPS
}

\author{
Azizah $^{1}$, Siti Nur Purwandhani, Dyah Titin Laswati
}

\begin{abstract}
Tortilla chips are corn-based preparations which have the characteristic yellow color, crunchy, thin, and easily crushed. Tortilla chips contain high carbohydrate but low protein content, to increase high protein content such as fish. The tortilla chips formula with Barracuda fish not only affects protein content but also affects chemical and organoleptic properties. The purpose of this study was to determine the differences in the quality of tortilla chips made with fortification of fresh and steamed barracuda fish with different concentrations of chemical and organoleptic characteristics. This research was conducted using 2 factorial RAL (Barracuda fish and concentration), namely the formula of Barracuda fish tortilla chips with 8 treatments and 3 replications. The observation variables were moisture content, ash content, fat content, protein content, carbohydrate content by difference, and organoleptic properties (crunchiness, color, flavor, and preference / overall). If there is a real effect, continue with DMRT (Duncan Multiple Range Test) at the 5\% level. The results showed that the tortilla chips formula treatment was significantly different in water content, fat content, protein content, carbohydrate content, and organoleptic properties. Meanwhile, the ash content was not significantly different. The best treatment formula for Barracuda fish tortilla chips in the treatment of fresh fish with a concentration of $7.5 \%$, namely with a moisture content of $3.76 \%$, an ash content of $4.23 \%$, a fat content of $36.07 \%$, a protein content of $6.83 \%$, a quality score of crispness. 4.3 (crunchy-very crispy), a flavor quality score of 2.5 (very little fish flavor), a color quality score of 3.8 (slightly yellow-yellow), and a favorite quality score of 4.1 (likevery much like it) ).
\end{abstract}

Keywords: mass corn, barracuda fish, tortilla chips.

\begin{abstract}
ABSTRAK
Tortilla chips adalah olahan berbahan dasar jagung yang memiliki karakteristik berwarna kuning, renyah, tipis, dan mudah hancur. Tortilla chips mengandug karbohidrat yang tinggi tetapi kandungan proteinnya rendah, untuk meningkatkan kadar protein yang tinggi seperti ikan. Formula tortilla chips dengan ikan Barakuda tidak hanya mempengaruhi kadar protein tetapi juga mempengaruhi sifat kimia dan organoleptik. Tujuan penelitian ini untuk mengetahui perbedaan kualitas tortilla chips yang dibuat dengan fortifikasi daging ikan Barakuda segar dan kukus dengan konsentrasi yang berbeda terhadap karakteristik kimia dan organoleptik. Penelitian ini dilakukan dengan menggunakan RAL 2 Faktorial (ikan Barakuda dan konsentrasi) yaitu formula tortilla chips ikan Barakuda dengan 8 perlakuan dan 3 ulangan. Variabel pengamatan yaitu kadar air, kadar abu, kadar lemak, kadar protein, kadar karbohidrat by difference, dan sifat organoleptik (kerenyahan, warna, flavor, dan kesukaan/overall). Apabila terjadi pengaruh nyata dilanjutkan dengan DMRT (Duncan Multiple Range Test) pada taraf 5\%. Hasil penelitian menunjukkan bahwa perlakuan formula tortilla chips berbeda nyata pada kadar air, kadar lemak, kadar protein, kadar karbohidrat, dan sifat organoleptik. Sedangkan kadar abu tidak berbeda nyata. Perlakuan formula tortilla chips ikan Barakuda yang terbaik pada perlakuan ikan segar konsentrasi 7,5\% yaitu dengan kadar air 3,76\%, kadar abu 4,23\%, kadar lemak 36,07\%, kadar protein 6,83\%, skor mutu kerenyahan 4,3 (renyah-sangat renyah), skor mutu flavor 2,5 (sangat sedikit-sedikit flavor ikan), skoring mutu warna 3,8 (sedikit kuning-kuning), dan skor mutu kesukaan 4,1 (suka-sangat suka).
\end{abstract}

Kata kunci : jagung masa, ikan barakuda, tortilla chips.

\section{PENDAHULUAN}

Pola konsumsi pangan masyarakat saat ini cenderung tidak sehat dan kurang beragam dari jenis pangan dan keseimbangan gizinya. Ini bertolak belakang dengan tujuan Gerakan Konsumsi Pangan Beragam Bergizi Seimbang
(B2SA) untuk meningkatkan kesadaran dan membudayakan pola konsumsi pangan beragam, bergizi, seimbang, aman untuk hidup sehat, aktif, dan produktif kepada masyarakat.

Indonesia merupakan negara dengan tingkat konsumsi camilan yang tinggi. Pesatnya

\footnotetext{
${ }^{1}$ Program Studi Teknologi Pangan Fakultas Sains dan Teknologi Universitas Widya Mataram Yogyakarta \azizahh@gmail.com
} 
perkembangan snack di Indonesia terjadi karena konsumsi camilan merupakan salah satu bagian dari gaya hidup khususnya anak-anak dan orang dewasa. Oleh karena itu, camilan bukan hanya sekedar makanan ringan sebagai asupan tubuh tetapi mengarah pada lifestyle. Banyak orang menggunakan momen menikmati 'ngemil' untuk membangun kedekatan sosial, koneksi, dan bahkan membentuk identitas pribadi mereka.

Snacks merupakan makanan ringan yang dikonsumsi di antara hidangan utama (makan pagi, makan siang, dan makan malam) yang berkontribusi menyumbang energi dan zat gizi. Namun nilai gizi dari makanan ringan ini masih terbatas. Snack yang beredar di pasar tidak memiliki keseimbangan nilai gizi, tinggi kalori dan tinggi Monosodium Glutamate (Purwaningsih et al., 2012). Perhimpunan Dokter Spesialis Gizi Klinik Indonesia (PDGKI) merekomendasikan konsumsi MSG dalam sehari tidak boleh lebih dari $10 \mathrm{mg} / \mathrm{kgBB}$ atau $0,1 \mathrm{gram} / \mathrm{kgBB}$. Jika berat badan seseorang $60 \mathrm{~kg}$ maka ia hanya boleh mengonsumsi MSG 6 gram, atau setara dengan setengah sendok teh dalam sehari. Makanan selingan berupa makanan ringan (Snack food) umumnya disukai oleh semua golongan umur baik anak-anak, remaja maupun orang dewasa karena cepat dan mudah ditemukan. Sebagai tambahan, snack modern memiliki berbagai macam bentuk, rasa, tekstur dan kemasan. Salah satu jenis snacks adalah tortilla chips.

Tortilla chips merupakan makanan khas dari Meksiko berbentuk keripik dengan bahan baku jagung yang dibuat melalui proses pemasakan, penggilingan, pengeringan, dan penggorengan. Tortilla memiliki ketidakseimbangan nilai gizi, yaitu tinggi karbohidrat dan rendah protein, karena itu menggunakan jagung sebagai bahan utama. Tortilla chips memiliki kandungan karbohidrat dan protein 80/100 g dan 11/100 g (Santoso et al, 2006). Salah satu upaya yang dapat dilakukan untuk meningkatkan kandungan gizi pada tortilla chips yaitu dengan melakukan fortifikasi. Fortifikasi yang dapat dilakukan diantaranya dengan memanfaatkan hasil perikanan berupa ikan. Ariani (2010) menyatakan bahwa pemenuhan kebutuhan protein masyarakat
Indonesia masih tertumpu pada protein nabati. Disisi lain hasil perikanan memiliki potensi yang baik untuk pemenuhan gizi masyarakat, khususnya protein hewani. Oleh karena itu, perlu menambahkan bahan yang kaya protein, salah satunya adalah ikan.

Ikan merupakan sumber nutrisi yang lengkap terutama protein hewani yang tinggi, asam amino yang lengkap dan asam lemak omega-3 yang lebih baik jika dibandingkan bahan pangan bersumber protein yang lain dan tentunya sangat baik untuk tubuh. Ada beberapa metode penambahan ikan pada pembuatan tortilla chips yaitu metode penambahan ikan segar dan metode penambahan ikan kukus. Oleh karena itu, untuk mengetahui pengaruh dari beberapa metode tersebut maka dilakukanlah penelitian ini agar mengetahui metode penambahan apa yang paling disukai oleh masyarakat. Selain itu, seperti yang diketahui ikan memiliki bau amis yang banyak tidak sukai. Maka dari itu, pada penelitian ini diberikan penambahan konsentrasi ikan yang berbeda untuk mengetahui konsentrasi berapa yang masih diterima oleh masyarakat.

Berdasarkan nilai gizi yang tinggi, salah satu jenis ikan yang memiliki potensi untuk dikembangkan adalah ikan Barakuda atau nama lokal di Bangka Belitung yaitu ikan ucul/alu-alu. Ikan Barakuda merupakan salah satu jenis komoditas perikanan yang mempunyai nilai ekonomis di Indonesia. Data statistik perikanan tangkap menurut Anonim (2018), produksi perikanan tangkap ikan Barakuda di Indonesia mengalami peningkatan dari tahun 2017 adalah $22.582,21$ ton menjadi $28.932,38$ ton pada tahun 2018. Statistik perikanan Indonesia selama lima tahun terakhir (2014-2018) menunjukkan produksi ikan Barakuda mengalami fluktuasi (antara 4.343,74 ton s/d 9.011,26 ton).

Pilihan untuk menambahkan daging ikan Barakuda (Sphyraena jello) bukan hanya karena tinggi proteinnya, tetapi karena karakteristik daging ikan itu sendiri. Ikan ini sering dikonsumsi oleh masyarakat karena memiliki daging yang berwarna putih, tekstur daging yang lembut, rasanya enak dan gurih serta dapat diolah menjadi berbagai macam masakan sehingga memiliki nilai jual yang tinggi dibandingkan dengan nilai jual yang tidak diolah. Penambahan 
daging ikan Barakuda dalam tortilla chips diharapkan dapat meningkatkan nilai gizi tortilla chips, terutama protein, sehingga bisa memenuhi kebutuhan nutrisi masyarakat.

\section{BAHAN DAN METODE}

Bahan

Bahan-bahan yang digunakan dalam penelitian ini terdiri dari bahan utama, yaitu ikan Barakuda (Sphyraena jello) yang berasal dari Pasar Kranggan Tugu, Yogyakarta dan Jagung pipil kering (Zea mays) yang berasal dari kebun jagung milik warga, Sleman serta bahan-bahan pendukung untuk proses pengadonan, bahan kimia untuk analisa proksimat dan organoleptik meliputi tepung tapioka, bawang putih, garam, baking soda, aquadest, Katalisator, $\mathrm{H}_{2} \mathrm{SO}_{4}, \mathrm{H}_{3} \mathrm{BO}_{3}$, $\mathrm{Na}_{2} \mathrm{~S}_{2} \mathrm{O}_{3}, \mathrm{NaOH}, \mathrm{HCl}$, indikator metilen red-blue, dan pelarut heksana.

Alat-alat yang digunakan dalam proses pembuatan tortilla chips ikan Barakuda meliputi timbangan, baskom, nampan, blender, pisau, sendok stainless steel, sendok kayu, oven, roller kayu. Sedangkan peralatan analisa yaitu cawan alumunium, pipet tetes, gelas beker, corong, oven(pengering), cawan porselen, thermometer, gelas ukur, desikator, neraca analitik, erlenmeyer, labu kjedal, labu soxhlet dan alat distilasi.

\section{Analisa data}

Rancangaan percobaan yang akan digunakan adalah Rancangan Acak Lengkap (RAL), faktorial dengan dua faktor yang diuji yaitu jenis ikan (segar dan kukus) dengan taraf konsentrasi yang berbeda $(0 \% ; 2,5 \% ; 5 \%$; dan $7,5 \%)$ dengan 8 kombinasi perlakuan. Parameter penelitian yaitu kadar air, abu, protein, lemak, karbohidrat, dan kesukaan dianalisis dengan analisis sidik ragam Analysis of Variance (ANOVA). ANOVA untuk mengetahui perlakuan yang digunakan dalam penelitian berpengaruh nyata atau tidak. Jika nilai $\mathrm{P}$ dan apabila ada perbedaan antar perlakuan dilanjutkan dengan uji duncan multiple range test dengan taraf $5 \%$.

\section{HASIL DAN PEMBAHASAN Kadar Air}

Pengukuran kadar air dilakukan untuk mengetahui pengaruh formula tortilla chips ikan
Barakuda terhadap kadar air yang dihasilkan. Hasil uji Duncan Multiple Range Test (DMRT) pada taraf 5\% kadar air tortilla chips dengan perlakuan ikan segar dan ikan kukus diperoleh hasil yang dapat dilihat pada Tabel 1 .

Tabel 1. Kadar air tortilla chips dengan perlakuan ikan segar dan ikan kukus

\begin{tabular}{ccc}
\hline Perlakuan & Rerata $(\%)$ & Notasi \\
\hline segar & 3,50 & $\mathrm{a}$ \\
kukus & 5,86 & $\mathrm{~b}$ \\
\hline
\end{tabular}

Keterangan :

Huruf yang berbeda menandakan adanya interaksi pada perlakuan (Berbeda Nyata).

Berdasarkan analisa varian menyatakan ada pengaruh nyata antar perlakuan yang dilakukan $(\mathrm{F}$ hitung > F tabel). Kemudian berdasarkan hasil uji DMRT taraf $5 \%$ perlakuan ikan Barakuda terhadap kadar air tortilla chips dapat dilihat pada Tabel 1 bahwa ikan Barakuda segar berbeda nyata secara signifikan dengan ikan Barakuda kukus. Kadar air ikan kukus lebih tinggi dibandingkan kadar air ikan segar (mentah). Diduga adanya air terikat karena bentuk air tersebut sulit diuapkan dan berikatan kuat. Selain itu, diduga adanya peran protein dengan molekul air yang bersifat hidrofilik dan hidrofobik dalam mengikat air pada tortilla chips. Menurut Kusnandar (2010), interaksi antara molekul air dengan sisi hidrofilik protein terjadi melalui ikatan hidrogen. Faktorfaktor utama yang mempengaruhi daya ikat air dari protein adalah konsentrasi protein, kekuatan ion, dan suhu.

Hasil analisa kadar air tortilla chips dengan perlakuan perbedaan konsentrasi dapat dilihat pada tabel berikut.

Tabel 2. Kadar air tortilla chips dengan perlakuan konsentrasi ikan segar dan ikan kukus

\begin{tabular}{ccc}
\hline Konsentrasi & Rerata (\%) & Notasi \\
\hline $0 \%$ & 3,63 & $\mathrm{a}$ \\
$2,5 \%$ & 4,87 & $\mathrm{~b}$ \\
$5 \%$ & 4,97 & $\mathrm{~b}$ \\
$7,5 \%$ & 5,25 & $\mathrm{~b}$ \\
\hline
\end{tabular}

Keterangan :

Huruf yang berbeda menandakan adanya interaksi pada perlakuan (Berbeda Nyata).

Hasil uji analisa varian/ANOVA perlakuan konsentrasi ikan segar dan kukus berbeda nyata terhadap kadar air tortilla chips. Dilanjut uji beda nyata DMRT taraf 5\% terlihat pada Tabel 2 
menunjukkan konsentrasi $0 \%$ berbeda nyata pada konsentrasi $2,5 \%$ - 7,5\% tetapi pada konsentrasi $2,5 \%-7,5 \%$ tidak berbeda nyata. Hal ini dikarenakan kadar air tortilla chips dipengaruhi oleh penambahan ikan sedangkan konsentrasi $0 \%$ tidak dilakukan penambahan (tanpa ikan). Semakin tinggi konsentrasi protein, jumlah air yang terikat juga semakin meningkat. Akan tetapi, suhu pemanasan yang tinggi dapat menurunkan jumlah air yang terikat (Kusnandar, 2010).

Interaksi kadar air perlakuan ikan dan konsentrasi ikan tortilla chips ikan Barakuda dapat dilihat pada Tabel 3.

Tabel 3. Interaksi kadar air perlakuan ikan dan konsentrasi ikan tortilla chips.

\begin{tabular}{lccccc}
\hline \multirow{2}{*}{ Perlakuan } & \multicolumn{4}{c}{ Konsentrasi (\%) } & Rerata \\
\cline { 2 - 5 } & 0 & 2,5 & 5 & 7,5 & $(\%)$ \\
\hline $\begin{array}{l}\text { Segar } \\
\text { Kukus }\end{array}$ & $3,28^{\mathrm{a}}$ & $3,46^{\mathrm{a}}$ & $3,49^{\mathrm{ab}}$ & $3,76^{\mathrm{ab}}$ & 3,50 \\
$\begin{array}{l}\text { Rerata } \\
(\boldsymbol{\%})\end{array}$ & $3,29^{\mathrm{b}}$ & $6,44^{\mathrm{c}}$ & $6,74^{\mathrm{c}}$ & 5,86 \\
\hline
\end{tabular}

Keterangan :

Huruf yang berbeda menandakan adanya interaksi pada perlakuan (Berbeda Nyata).

Berdasarkan hasil uji DMRT taraf 5\% pada Tabel 3 terlihat bahwa interaksi kadar air meningkat tiap perlakuan. Kadar air berkisar antara 3,28\% - 6,74\%. Kadar air tertinggi dicapai oleh perlakuan ikan kukus $7,5 \%$ ikan dari total adonan ("masa" jagung dan tepung tapioka) sebesar $6,74 \%$. Sebaliknya, kadar air terendah pada perlakuan ikan segar $0 \%$ (kontrol) sebesar $3,28 \%$. Perlakuan ikan segar $0 \%$ tidak berpengaruh nyata pada perlakuan ikan segar 2,5\%; 5\%; dan 7,5\% tetapi berpengaruh nyata secara signifikan ikan kukus $0 \% ; 2,5 \%$; $5 \%$; dan $7,5 \%$.

Hasil penelitian Fathiarisa (2016) menunjukkan kadar air produk tortilla chips komersil yaitu sebesar 4,12\%. Hal tersebut menunjukkan bahwa kadar air pada tortilla chips diatas kadar air tortilla chips komersil. Perbedaan tersebut dapat disebabkan oleh perbedaan bahanbahan yang digunakan. Pada tortilla chips komersial menggunakan bahan utama jagung yang mengandung kadar air sebesar 13,5\% (Koswara, 2009) dan tidak menggunakan ikan, sedangkan pada tortilla chips ikan terdapat ikan
Barakuda segar dan ikan kukus serta tepung tapioka.

Kenaikan kadar air pada perlakuan ikan kukus 2,5\%; 5\%; dan 7,5\% dibandingkan perlakuan ikan segar disebabkan oleh sifat air dan peranan protein dalam tortilla chips. Diduga adanya air yang bersifat terikat sehingga dengan suhu tinggi tidak bisa diuapkan dan kemampuan tortilla dalam mengikat air tidak terlepas dari peran protein. Protein memiliki sifat hidrofilik dan hidrofobik, dimana sisi hidrofilik akan mengikat air dan sisi hidrofobik akan mengikat lemak (Kusnandar, 2010). Interaksi antara protein dan air terjadi pada sisi asam amino polar pada protein yaitu gugus sulfihidril. Sebagian protein yang terdapat pada daging ikan mengandung sisi rantai polar tersebut pada sepanjang kerangka peptida yang menyebabkan senyawa tersebut bersifat hidrofilik, sehingga pada interval penggunaan suhu dan waktu pemanasan yang sama dengan kandungan protein yang semakin besar akan mempunyai kadar air yang semakin besar (Haryadi, 1997 dalam Syakur, 2002).

\section{Kadar abu}

Abu adalah zat organik sisa hasil pembakaran suatu bahan organik. Bahan pangan mengandung mineral yang berbentuk abu. Mineral pada bahan pangan terbagi menjadi garam organik dan garam anorganik. Hasil uji Duncan Multiple Range Test (DMRT) pada taraf 5\% kadar abu tortilla chips dengan perlakuan ikan segar dan ikan kukus diperoleh hasil yang dapat dilihat pada Tabel 4.

Tabel 4. Kadar abu tortilla chips dengan perlakuan ikan segar dan ikan kukus

\begin{tabular}{ccc}
\hline Perlakuan & Rerata $(\%)$ & Notasi \\
\hline segar & 3,98 & a \\
kukus & 4,00 & a \\
\hline
\end{tabular}

Keterangan :

Huruf yang berbeda menandakan adanya interaksi pada perlakuan (Berbeda Nyata).

Berdasarkan hasil analisa varian/ANOVA perlakuan ikan segar dan kukus tidak berbeda nyata terhadap kadar abu tortilla chips yang difortifikasi dengan ikan Barakuda. Hal ini diduga karena kadar abu stabil terhadap pemanasan, kadar abu daging ikan segar dan ikan kukus sangat kecil sehingga tidak mempengaruhi kadar 
abu tortilla. Nilai rata-rata kadar abu perlakuan ikan segar yaitu 3,98\% dan ikan kukus yaitu 4,00\%. Kadar abu produk tortilla chips komersil yaitu 3,70\% (Fathiarisa, 2016). Kadar abu tortilla chips yang dihasilkan lebih besar dari abu tortilla chips komersil. Menurut deMan (1997), kadar abu berkaitan dengan kandungan mineral dalam bahan. Mineral dalam bahan pangan ditentukan dengan pembakaran. Proses pembakaran tersebut merusak senyawa organik dan meninggalkan mineral. Mineral yang terkandung dalam tortilla chips ini dipengaruhi oleh kandungan mineral daging ikan tersebut.

Hasil analisa kadar abu tortilla chips dengan perlakuan perbedaan konsentrasi ikan dapat dilihat pada Tabel 5.

Tabel 5. Kadar abu tortilla chips dengan perlakuan konsentrasi ikan segar dan ikan kukus

\begin{tabular}{ccc}
\hline Konsentrasi & Rerata (\%) & Notasi \\
\hline $0 \%$ & 3,76 & $\mathrm{a}$ \\
$2,5 \%$ & 3,99 & $\mathrm{a}$ \\
$5 \%$ & 4,09 & $\mathrm{a}$ \\
$7,5 \%$ & 4,15 & $\mathrm{a}$ \\
\hline
\end{tabular}

Keterangan :

Huruf yang berbeda menandakan adanya interaksi pada perlakuan (Berbeda Nyata).

Hasil uji ANOVA perlakuan konsentrasi ikan tidak mengalami berbeda nyata. Mineral yang terkandung dalam tortilla chips dipengaruhi oleh kandungan mineral ikan yang ditambahkan. Diduga kadar abu daging ikan barakuda hanya sedikit sehingga tidak mempengaruhi kadar abu tortilla dan kadar abu stabil terhadap pemanasan. Nilai rata-rata kadar abu perlakuan konsentrasi $0 \%$ yaitu $3,76 \%$, konsentrasi $2,5 \%$ yaitu $3,99 \%$, konsentrasi $5 \%$ yaitu $4,09 \%$ dan konsentrasi $7,5 \%$ yaitu $4,15 \%$.

\section{Kadar lemak}

Lemak adalah senyawa ester non-polar yang tidak larut dalam air (Kusnandar, 2010). Hasil uji Duncan Multiple Range Test (DMRT) pada taraf 5\% kadar lemak tortilla chips dengan perlakuan ikan segar dan ikan kukus diperoleh hasil yang dapat dilihat pada Tabel 6 .
Tabel 6. Kadar lemak tortilla chips dengan perlakuan ikan segar dan ikan kukus

\begin{tabular}{ccc}
\hline Perlakuan & Rerata $(\%)$ & Notasi \\
\hline segar & 27,67 & a \\
kukus & 27,84 & a \\
\hline
\end{tabular}

\section{Keterangan :}

Huruf yang berbeda menandakan adanya interaksi pada perlakuan (Berbeda Nyata).

Berdasarkan hasil ANOVA perlakuan ikan segar dan ikan kukus tidak berbeda nyata. Hal ini diduga karena lemak memiliki sifat yang stabil terhadap pemanansan. Oleh karena itu, penambahan ikan segar dan ikan kukus tidak mempengaruhi kadar lemak tortilla chips. Ditambah peran protein yang bersifat hidrofobik, dimana sisi hidrofobik dapat mengikat lemak pada tortilla chips. Nilai rata-rata kadar lemak perlakuan ikan segar yaitu 27,67\% dan ikan kukus yaitu $27,84 \%$.

Hasil analisa kadar lemak tortilla chips dengan perlakuan konsentrasi ikan dapat dilihat pada tabel berikut.

Tabel 7. Kadar lemak tortilla chips dengan perlakuan konsentrasi ikan segar dan ikan kukus

\begin{tabular}{ccc}
\hline Konsentrasi & Rerata (\%) & Notasi \\
\hline $0 \%$ & 20,13 & $\mathrm{a}$ \\
$2,5 \%$ & 23,95 & $\mathrm{a}$ \\
$5 \%$ & 30,40 & $\mathrm{~b}$ \\
$7,5 \%$ & 36,52 & $\mathrm{c}$ \\
\hline
\end{tabular}

Keterangan :

Huruf yang berbeda menandakan adanya interaksi pada perlakuan (Berbeda Nyata).

Hasil uji DMRT taraf 5\% perlakuan konsentrasi ikan berbeda nyata terhadap perlakuan yang dilakukan. Disebabkan oleh bahan baku yang digunakan mengandung lemak dengan konsentrasi yang berbeda. Nilai rata-rata kadar lemak perlakuan konsentrasi $0 \%$ yaitu $20,13 \%$, konsentrasi 2,5\% yaitu 23,95\%, konsentrasi $5 \%$ yaitu 30,40\% dan konsentrasi 7,5\% yaitu 36,52\%. Konsentrasi $0 \%$ berbeda nyata dengan konsentrasi 5\% dan 7,5\% karena konsentrasi 0\% tanpa penambahan ikan. Ini berarti perlakuan konsentrasi ikan dapat mempengaruhi kadar lemak tortilla kecuali pada konsentrasi 2,5\%. Hal ini diduga konsentrasi $2,5 \%$ terlalu sedikit sehingga tidak berbeda nyata dengan konsentrasi tanpa ikan (kontrol). 
Interaksi kadar lemak perlakuan ikan dan konsentrasi ikan tortilla chips ikan Barakuda dapat dilihat pada Tabel 8 .

Tabel 8. Interaksi kadar lemak perlakuan ikan dan konsentrasi ikan tortilla chips

\begin{tabular}{|c|c|c|c|c|c|}
\hline \multirow{2}{*}{$\begin{array}{c}\text { Perlakua } \\
\text { n }\end{array}$} & \multicolumn{4}{|c|}{ Konsentrasi (\%) } & \multirow{2}{*}{$\begin{array}{l}\text { Rerat } \\
\text { a }(\%)\end{array}$} \\
\hline & 0 & 2,5 & 5 & 7,5 & \\
\hline \multirow{2}{*}{ Segar } & $\underset{\mathrm{a}}{19,84}$ & $\underset{\mathrm{b}}{26,48}$ & $\underset{\mathrm{b}}{28,26}$ & $\underset{\mathrm{c}}{36,07}$ & 27,66 \\
\hline & 20,40 & 21,42 & 32,55 & 36,97 & 27,83 \\
\hline $\begin{array}{l}\text { Kukus } \\
\text { Rerata }\end{array}$ & 2012 & 2395 & 3040 & 3652 & \\
\hline
\end{tabular}

Keterangan :

Huruf yang berbeda menandakan adanya interaksi pada perlakuan (Berbeda Nyata).

Hasil pengujian ANOVA menunjukkan bahwa interaksi perlakuan ikan dan konsentrasi ikan memberi pengaruh terhadap kadar lemak pada tortilla chips yang dihasilkan. Kadar lemak tortilla chips berkisar antara $19,84 \%$ sampai $36,97 \%$. Kadar lemak tertinggi terdapat pada tortilla chips dengan penambahan ikan kukus 7,5\% dan ikan segar 7,5\%, sedangkan kadar lemak terendah ditunjukkan oleh tortilla chips dengan penambahan ikan segar sebesar 19,84\% dan ikan kukus $0 \%$ sebesar 20,40\%. Kadar lemak produk tortilla chips komersil yaitu sebesar 22,32\% (Fatiarisa, 2016). Standar nasional untuk keripik tortila belum ada, produk ini dapat didekatkan dengan SNI 2886:2015 tentang makanan ringan ekstrudat yang mensyaratkan kadar lemak dengan proses penggorengan maksimal 38\% (Anonim, 2000).

Tabel 8 menunjukkan bahwa semakin banyak ikan yang ditambahkan maka semakin tinggi pula kandungan lemak. Hal tersebut disebabkan oleh bahan yang digunakan dan metode yang digunakan, terutama bahan baku yang mengandung lemak (Sari, 2013). Proses penggorengan menyebabkan peningkatan kadar lemak tortilla chips. Pada proses penggorengan terjadi proses perpindahan masa air dan minyak yang ditandai dengan hilangnya sejumlah air dari tortila dan terabsorbsinya minyak ke dalam tortila.

\section{Kadar protein}

Hasil uji Duncan Multiple Range Test (DMRT) pada taraf 5\% kadar protein tortilla chips dengan perlakuan ikan segar dan kukus diperoleh hasil yang dapat dilihat pada Tabel 9.

Tabel 9. Kadar protein tortilla chips dengan perlakuan ikan segar dan kukus

\begin{tabular}{ccc}
\hline Perlakuan & Rerata (\%) & Notasi \\
\hline segar & 4,97 & $\mathrm{a}$ \\
kukus & 6,57 & $\mathrm{a}$ \\
\hline
\end{tabular}

Keterangan :

Huruf yang berbeda menandakan adanya interaksi pada perlakuan (Berbeda Nyata).

Berdasarkan analisa varian/ANOVA menyatakan tidak ada pengaruh nyata antar perlakuan ikan segar dan ikan kukus sehingga tidak mempengaruhi kadar protein tortilla. Diduga asam amino yang bersifat hidrofilik secara umum akan berada di sisi permukaan luar yang berikatan dengan air di sekelilingnya. Kadar protein ikan kukus lebih tinggi dibandingkan ikan segar, sesuai dengan penelitian Pradana (2013) bahwa kandungan protein kasar (crude protein) daging ikan Barakuda setelah pengukusan mengalami perubahan dari $14,71 \%$ menjadi $20,45 \%$ (bb). Sedangkan kadar protein dry basis ikan segar 76,18\% dan ikan kukus 71,50\% (bk).

Hasil analisa kadar protein tortilla chips dengan perlakuan perbedaan konsentrasi ikan dapat dilihat pada Tabel 10.

Tabel 10. Kadar protein tortilla chips dengan perlakuan konsentrasi ikan segar dan ikan kukus

\begin{tabular}{ccc}
\hline Konsentrasi & Rerata (\%) & Notasi \\
\hline $0 \%$ & 3,69 & a \\
$2,5 \%$ & 4,83 & a \\
$5 \%$ & 6,72 & a \\
$7,5 \%$ & 7,84 & b \\
\hline
\end{tabular}

Keterangan :

Huruf yang berbeda menandakan adanya interaksi pada perlakuan (Berbeda Nyata).

Berdasarkan analisa varian/ANOVA perlakuan konsentrasi ikan segar dan kukus berbeda nyata terhadap kadar protein tortilla chips. Dilanjut uji beda nyata DMRT taraf 5\% menunjukkan konsentrasi $0 \%$ berbeda nyata dengan konsentrasi 7,5\% tetapi konsentrasi $0 \%$ $5 \%$ tidak berbeda nyata. Hal ini diduga penambahan konsentrasi ikan $0 \%-5 \%$ dapat menaikkan kadar protein tetapi tidak signifkan. Kadar protein tertinggi yaitu konsentrasi 7,5\% sebesar 7,84\% dan kadar protein terendah yaitu konsentrasi 0\% (kontrol) sebesar 3,69\%. Protein 
ikan Barakuda memberikan sumbangan terbesar yang mempengaruhi kadar protein tortilla chips, Semakin besar jumlah konsentrasi ikan yang ditambahkan maka semakin besar pula kadar protein yang terkandung.

Interaksi antara protein dan air terjadi pada sisi asam amino polar pada protein yaitu gugus sulfihidril. Sebagian protein yang terdapat pada daging ikan mengandung sisi rantai polar tersebut pada sepanjang kerangka peptida yang menyebabkan senyawa tersebut bersifat hidrofilik, sehingga pada interval penggunaan suhu dan waktu pemanasan yang sama dengan kandungan protein yang semakin besar akan mempunyai kadar air yang semakin besar (Haryadi, 1997 dalam Syakur, 2002).

Interaksi kadar protein perlakuan ikan dan konsentrasi ikan tortilla chips ikan Barakuda dapat dilihat pada Tabel 11.

Tabel 11. Interaksi kadar protein perlakuan ikan dan konsentrasi ikan tortilla chips

\begin{tabular}{lccccc}
\hline Perlakuan & \multicolumn{4}{c}{ Konsentrasi (\%) } & Rerata \\
\cline { 2 - 4 } & 0 & 2,5 & 5 & 7,5 & \\
\hline Segar & $3,67^{\mathrm{a}}$ & $4,10^{\mathrm{a}}$ & $5,25^{\mathrm{a}}$ & $6,8^{\mathrm{a}}$ & 4,95 \\
Kukus & $3,70^{\mathrm{a}}$ & $5,56^{\mathrm{a}}$ & $8,19^{\mathrm{b}}$ & $8,84^{\mathrm{b}}$ & 6,57 \\
\hline Rerata & 3,68 & 4,83 & 6,72 & 7,82 & \\
$\quad$ Keterangan : & & & & \\
\multicolumn{1}{l}{ Huruf yang berbeda menandakan adanya interaksi } \\
\multicolumn{2}{l}{ pada perlakuan (Berbeda Nyata). }
\end{tabular}

Hasil pengujian ANOVA menunjukkan bahwa interaksi perlakuan ikan dan konsentrasi ikan memberi pengaruh terhadap kadar protein pada tortilla chips yang dihasilkan. Dilanjut uji Duncan Multiple Range Test (DMRT) taraf 5\% perlakuan ikan segar $0 \%$ berbeda nyata dengan ikan kukus 5\% dan ikan kukus 7,5\% karena penambahan ikan dengan konsentrasi yang berbeda dapat mempengaruhi kadar protein tortilla.

Sumber protein pada penelitian ini berasal dari ikan Barakuda dan jagung. Kadar protein tortilla chips berkisar antara $3,67 \%$ sampai $8,84 \%$. Kadar protein tertinggi terdapat pada tortilla chips dengan penambahan ikan kukus 7,5\% dan ikan kukus 5\%, sedangkan kadar protein terendah ditunjukkan oleh tortilla chips dengan penambahan ikan segar 0\% dan ikan kukus 0\%. Perbedaan antara tortilla chips ikan Barakuda dengan tortilla chips komersial yaitu kandungan protein tortilla chips berasal dari bahan baku yang digunakan. Kadar protein produk tortilla chips komersil yaitu sebesar 7,74\% (Fatiarisa, 2016).

Proses formula tortilla chips ikan Barakuda melewati beberapa proses pemanasan yaitu pengukusan dan penggorengan. Proses pemanasan tersebut dapat mempengaruhi keterikatan protein pada ikan dengan pati jagung. Menurut Gaonkar dan McPherson (2005), proses pemanasan akan meningkatkan keterkaitan pati dan protein. Proses pemanasan pada protein menyebabkan terjadinya peningkatan proses denaturasi yang dibantu dengan adanya air. Pada saat protein dan pati berikatan maka akan terbentuk matriks proteinpati yang stabil melibatkan ikatan hidrogen, ikatan kovalen, dan rantai ionik.

\section{Kadar karbohidrat by difference}

Kadar karbohidrat ditentukan secara by difference, yaitu hasil pengurangan dari $100 \%$ dengan kadar air, abu, protein dan lemak. Perhitungan nilai karbohidrat yang didapat merupakan proporsional dari perhitungan keseluruhan proksimat. Hasil analisa perlakuan ikan segar dan ikan kukus dapat dilihat pada Tabel 12.

Tabel 12. Kadar karbohidrat tortilla chips dengan perlakuan ikan segar dan ikan kukus

\begin{tabular}{ccc}
\hline Perlakuan & Rerata $(\%)$ & Notasi \\
\hline segar & 59,87 & a \\
kukus & 55,71 & a \\
\hline
\end{tabular}

Keterangan :

Huruf yang berbeda menandakan adanya interaksi pada perlakuan (Berbeda Nyata).

Berdasarkan hasil uji ANOVA perlakuan ikan segar dan kukus tidak berbeda nyata secara signifikan terhadap kadar karbohidrat tortilla chips yang difortifikasi dengan ikan Barakuda. Ini terjadi karena ikan segar dan ikan kukus tidak mempengaruhi kadar karbohidrat tortilla. Nilai rata-rata kadar karbohidrat perlakuan ikan segar yaitu 59,87\% dan ikan kukus yaitu 55,71\%.

Hasil analisa kadar karbohidrat tortilla chips dengan perlakuan konsentrasi ikan dapat dilihat pada Tabel 13. 
Tabel 13. Kadar karbohidrat tortilla chips dengan perlakuan konsentrasi ikan segar dan ikan kukus

\begin{tabular}{ccc}
\hline Konsentrasi & Rerata (\%) & Notasi \\
\hline $0 \%$ & 68,82 & $\mathrm{a}$ \\
$2,5 \%$ & 62,35 & $\mathrm{~b}$ \\
$5 \%$ & 53,80 & $\mathrm{c}$ \\
$7,5 \%$ & 46,20 & $\mathrm{~d}$ \\
\hline
\end{tabular}

Keterangan :

Huruf yang berbeda menandakan adanya interaksi pada perlakuan (Berbeda Nyata).

Hasil uji ANOVA perlakuan konsentrasi ikan segar dan kukus berbeda nyata secara signifikan terhadap kadar karbohidrat tortilla chips yang difortifikasi dengan ikan Barakuda. Nilai rata-rata kadar lemak perlakuan konsentrasi $0 \%$ yaitu $68,82 \%$, konsentrasi $2,5 \%$ yaitu $62,35 \%$, konsentrasi $5 \%$ yaitu $53,80 \%$ dan konsentrasi $7,5 \%$ yaitu $46,20 \%$. Dilanjut uji DMRT taraf 5\% konsentrasi $0 \%$ berbeda nyata dengan konsentrasi 2,5\%,5\% dan 7,5\%.

Hasil penelitian Fathiarisa (2016) menunjukkan kadar karbohidrat produk tortilla chips komersil yaitu sebesar $62,11 \%$. Perbedaan tersebut diduga karena penambahan ikan mengandung lebih banyak protein dan lemak. Tingginya kandungan karbohidrat pada tortilla chips tanpa penambahan ikan (0\%) disebabkan oleh jagung dalam jumlah tinggi. Penambahan ikan Barakuda pada tortilla chips akan menurunkan kadar penggunaan bahan baku yang menggunakan karbohidrat produk yang dihasilkan dan protein secara proporsional.

Interaksi kadar karbohidrat perlakuan ikan dan konsentrasi ikan tortilla chips ikan Barakuda dapat dilihat pada Tabel 14.

Tabel 14. Interaksi kadar karbohidrat perlakuan ikan \& konsentrasi ikan tortilla chips

\begin{tabular}{lccccc}
\hline Perlakuan & \multicolumn{4}{c}{ Konsentrasi (\%) } & Rerata \\
\cline { 2 - 4 } & 0 & 2,5 & 5 & 7,5 & \\
\hline \multirow{2}{*}{ Segar } & $69,69^{\mathrm{d}}$ & $61,96^{\mathrm{c}}$ & $58,82^{\mathrm{c}}$ & $49,01^{\mathrm{b}}$ & 59,87 \\
Kukus & $67,94^{\mathrm{d}}$ & $62,73^{\mathrm{c}}$ & $48,79^{\mathrm{b}} 43,39^{\mathrm{a}}$ & 55,71 \\
Rerata & 68,81 & 62,34 & 53,80 & 46,2 & \\
\hline
\end{tabular}

Keterangan :

Huruf yang berbeda menandakan adanya interaksi pad perlakuan (Berbeda Nyata).

Berdasarkan analisa varian pada tabel interaksi perlakuan ikan dan konsentrasi ikan berbeda nyata terhadap kadar karbohidrat tortilla. Dilanjut uji DMRT taraf 5\% menunjukkan ikan segar 0\% dan ikan kukus $0 \%$ berbeda nyata dengan ikan segar 2,5\%, ikan segar 5\%, ikan segar 7,5\%, ikan kukus 2,5\%, ikan kukus 5\%, dan ikan kukus 7,5\%. Hal ini disebabkan oleh perlakuan ikan kukus 0\% mempunyai kadar air lebih besar dibandingkan ikan segar 0\%, sehingga dalam berat yang sama ikan segar mempunyai kadar karbohidrat yang lebih besar dibandingkan dengan ikan kukus.

\section{Kesukaan}

Penerimaan kesukaan merupakan penerimaan panelis secara keseluruhan terhadap beberapa parameter yaitu rasa, warna, aroma dan tekstur dari produk. Penggujian dengan menggunakan uji Duncan Multiple Range Test pada taraf 5\% diperoleh hasil yang dapat dilihat pada Tabel 15.

Tabel 15. Organoleptik kesukaan tortilla chips ikan Barakuda

\begin{tabular}{lll}
\hline \multicolumn{1}{c}{ Perlakuan } & Rerata & \multicolumn{1}{c}{ Keterangan } \\
\hline ikan segar 0\% & $3,77^{\text {bcd }}$ & $5=$ Sangat suka \\
ikan segar 2,5\% & $3,93^{\text {cd }}$ & 4 = Suka \\
ikan segar 5\% & $3,47^{\text {bc }}$ & 3 = Sedikit suka \\
ikan segar 7,5\% & $4,13^{\mathrm{d}}$ & 2 = Tidak suka \\
ikan kukus 0\% & $3,47^{\text {bc }}$ & 1 = Sangat tidak suka \\
ikan kukus 2,5\% & $3,8^{\text {bcd }}$ & \\
ikan kukus 5\% & $3,43^{\mathrm{b}}$ & \\
ikan kukus 7,5\% & $2,87^{\mathrm{a}}$ & \\
\hline \multicolumn{3}{l}{ Keterangan : } \\
Huruf yang berbeda menandakan adanya interaksi \\
pada perlakuan (Berbeda Nyata).
\end{tabular}

Berdasarkan hasil uji ANOVA organoleptik kesukaan berbeda terhadap tortilla chips. Berdasarkan hasil uji lanjut DMRT pada taraf 5\% dari segi keseluruhan perlakuan ikan segar $0 \%$ berbeda nyata dengan ikan kukus 7,5\%. Berdasarkan hasil uji hedonik pada atribut kesukaan yang tersedia pada Tabel 15 hasil ratarata keseluruhan dari kesukaan panelis menunjukkan bahwa skor kesukaannya terletak pada skor 2,87- 4,13 (tidak suka, sedikit suka, suka dan sangat suka). Rata-rata panelis panelis paling menyukai perlakuan ikan segar 7,5\% dan ikan segar 2,5\% karena sangat renyah, rasa dan aroma ikan yang kuat, warna tortilla yang kuning kecoklatan, dan tentunya konsentrasi ikan yang banyak membuat panelis lebih suka dan berbeda dari tortilla chips komersial. 


\section{KESIMPULAN}

Berdasarkan uraian terdahulu dapat disimpulkan bahwa: banyaknya ikan Barakuda yang ditambahkan adalah 37,5 g atau 7,5\% dari total adonan $500 \mathrm{~g}$ ("Masa" jagung dan tepung tapioka), $25 \mathrm{~g}$ atau 5\% dari $500 \mathrm{~g}$ ("Masa" jagung dan tepung tapioka), 12,5 $\mathrm{g}$ atau 2,5\% dari total adonan $500 \mathrm{~g}$ ("Masa" jagung dan tepung tapioka) dan sebagai pembanding antar perlakuan yaitu 0 $\%$ (kontrol/tanpa ikan).

Semakin besar ikan Barakuda segar dan kukus pada pembuatan tortilla chips akan menaikkan sifat kimia (air, abu, lemak dan protein), namun menurunkan sifat kimia (karbohidrat). Sifat organoleptik yang terdiri dari kerenyahan, warna, flavour dan kesukaan mengalami fluktuatif.

Formula terpilih berdasarkan uji organoleptik dan pertimbangan uji tekstur serta kimia terutama kandungan protein yang tinggi adalah tortilla chips dengan penambahan ikan Barakuda segar 7,5\% yaitu sebanyak 37,5 g (7,\% dari total adonan $500 \mathrm{~g}$ "Masa" jagung dan tepung tapioka). Tortilla chips ikan Barakuda segar 7,5\% memiliki karakteristik mutu cenderung kuning, memiliki rasa gurih dan aroma ikan, tekstur renyah dan mudah dipatahkan dan sangat disukai panelis.

Kadar air, abu, lemak, protein, karbohidrat yang terdapat pada tortilla chips terpilih berturutturut sebesar 3,76\% (bb), 4,23\% (bk), 6,83\% (bk), $36,07 \%$ (bk). Sifat organoleptik kerenyahan 4,3 (renyah-sangat renyah), skor mutu flavor 2,5 (sangat sedikit-sedikit flavor ikan), skoring mutu warna 3,8 (sedikit kuning-kuning), dan skor mutu kesukaan 4,1 (suka-sangat suka). Jika dibandingkan dengan Tortilla Chips komersial kandungan proksimat tortilla chips ikan Barakuda terpilih lebih tinggi karena melewati proses penggorengan. Sementara itu, kadar abu dan protein lebih tinggi karena dengan penambahan ikan Barakuda membuat tortilla chips ikan Barakuda lebih unggul terutama dalam kandungan protein.

\section{DAFTAR PUSTAKA}

Anonim. 2000. Badan Standardisasi Nasional. 2000. SNI 01-2886-2000. Makanan ringan ekstrudat. Jakarta.
Anonim. 2018. KKP (Kementrian Kelautan dan Perikanan). Statistik Perikanan Tangkap Indonesia 2018. https://kkp.go.id/.

Ariani, M. 2010. Analisis Konsumsi Pangan Tingkat Masyarakat Mendukung Pencapaian Diversifikasi Pangan. Jurnal Gizi Indonesia. Vol, 33(1),20- 28.

Deman, M John. 1997. Kimia Makanan Bandung: ITB. Bandung

Fathiarisa NA. 2016. Studi pembuatan Tortilla Chips berbahan dasar tempe sebagai olahan snack food. Bogor (ID): Institut Pertanian Bogor.

Gaonkar, A.G., and McPherson, A. 2005. Ingredients Interaction Effect on Food Quality 2nd . CRC Press Taylor and Francis Group. New York.

Koswara. 2009. Seri Teknologi Pangan Populer Teknologi Pengolahan Mie.eBookPangan.com.http://tekpan.unimu s.ac.id/wpcontent/uploads/2013/07/Teknolo gi-Pengolahan-Mie-teori-dan-praktek.pdf. Diakses 30 Maret 2020.

Kusnandar, F. 2010. Kimia Pangan. Jakarta:Dian Rakyat.

Pradana G W. 2013. Karakteristik asam amino dan jaringan jaringan Ikan Barakuda (Sphyraena jello) segar dan kukus [Skripsi]. Jurusan Teknologi Hasil Perairan Fakultas Perikanan dan Ilmu Kelautan Institut Pertanian Bogor.

Purwaningsih S, Jacoeb dan AM, Dewi MM. 2012. Karakteristik dan kandungan gizi tsukada-Ni ikan jangilus (Istiophorus orientalis). Jurnal Inovasi dan Kewirausahaan I. 2012;2:98-104.

Santoso B, Nur H, dan Wahyu A. 2006. Tortilla. Trubus Agrisarana. Surabaya

Sari NK. 2013. Analisis tingkat kerenyahan oada keripik singkong, keripik kentang dan keripik pisang. [skripsi]. Makassar(ID): Universtias Hasanuddin Makassar.

Syakur, Abdul. 2002. Pengaruh Substitusi Ikan Nila Hitam Terhadap Sifat Kimia, Fisik, dan Organoleptik Tortilla Jagung (Zea mays) Yang Dihasilkan. [Skripsi]. Program Studi Teknologi Pangan dan Gizi. Fakultas Teknologi Pertanian. Universitas Widya Mataram. Yogyakarta. 